\title{
The Implementation of Psychosomatic Therapy in Obstetrics and Gynecology
}

\author{
Yasushi OKAMURA \\ Department of Obstetrics and Gynecology, School of Medicine, University of \\ Occupational and Environmental Health, Japan. Kitakyshu 807, Japan
}

Abstract: The mechanism of the development of disease has been considered under three aspects: psychology, endocrinology, and the autonomic nervous system. It is also important to make a diagnosis under the concept using conversion into numerical formula. The psychogenic situational factor should be paid attention to in diagnosis. In order to implement such diagnosis it is mandatory to organize a therapeutic team including a clinical psychologist and case worker. The author would like to analyze clinical cases from this view-point. In the United States, family practice, internal medicine, pediatrics and obstetrics and gynecology take charge of primary care. However, the specialist system in primary care is not yet established in Japan. It is important to continue further efforts in diagnosis and treatment from a bio-psycho-social aspect within related fields. The contents of this paper was summarized from the presentation as a symposist at the Meeting of the 5th Japan Primary Care Association held on June 12, 1982 and also from the speech given as a chairman of the symposium at the same meeting.

Key words: psychosomatic therapy, obstetrics-gynecology, clinical cases, analysis-concept of disease, team therapy.

(Received 14 August 1982)

The fractionation of clinical medicine has become more prominent within the past few years. Under the trend of specialization in larger hospitals, what type of responsible organization will accomplish a general integration which is indispensable in clinical medicine in the near future? Recently, many physicians have become interested in the problem of primary care. This fact is possibly due to the existence of anxiety. The author has been interested in this subject for sometime past, and has been trying to keep in contact with related clinical specializations. During the past twenty years he has exerted efforts not only on the social aspect, i.e. psychogenic situational aspect, but also on the biophychologic aspect, i.e. psychosomatic correlation, in the diagnosis and treatment of obstetric and gynecological diseases.

\section{Diagnosis in Psychosomatic Therapy}

The mechanism of development of disease has been considered under three aspects: psychology, endocrinology, and the autonomic nervous system. It is important to study 
Table 1. Analysis-concept of diseases

$$
\begin{gathered}
Z=\left\{\begin{array}{l}
f_{1}(x \cdot y t) \\
f_{2}(x \cdot y t)
\end{array}\right. \\
f_{1}: \text { Psychogenic fitness } \\
f_{2}: \text { Somatic fitness } \\
\mathrm{x}: \text { Genetic factor } \\
\mathrm{y}: \text { Situational factor } \\
\mathrm{t}: \text { Time factor } \\
\mathrm{z}: \text { Disease }
\end{gathered}
$$

disease under a new concept, as it is shown in Table 1.

Here $f_{1}$ represents psychogenic fitness, $f_{2}$ somatic fitness, $x$ genetic factor, $y$ situational factor, $t$ time factor, and $z$ disease. The author would like to present endocrine disorder as an example. The endocrine disorder that develops from $x$ in $f_{1}$ is of a congenital nature; anorexia nervosa belongs to this group. Mental conflict at home and anxiety at work may be cited as $y$ in $f_{1}$. The endocrine disorder of $x$ in $f_{2}$ occurs in cases of chromosomal disorders; Turner's syndrome and the testicular feminization syndrome are examples. Inadequate use of hormones, dietary restrictions to treat obesity, and massive postparturitional hemorrhage are examples of $y$ in $f_{2}$. The $t$ in $f_{1}$ means the period after a psychic load (mental stress) occurs, and $t$ in $f_{2}$ indicates the period after a somatic situational load occurs.

It is important to make a diagnosis under the concept using the conversion into a numerical formula as described above (Okamura et al., 1971, 1974). The psychogenic situational factor should be paid attention to in making the diagnosis. In order to implement such a diagnosis it is mandatory to organize a therapeutic team including a clinical psychologist and case worker (Okamura et al., 1982).

The author would like to present the following two cases.

Case 1. M. H. 26 years old, female, single.

$$
\left\{\begin{array}{l}
f_{1}(x \cdot y t) \\
f_{2}(x \cdot y t)
\end{array}\right.
$$

Her menstruation has been irregular since menarche at the age of 15 , and ovulation seems to rarely occur (Fig. 1). She has undergone hormon therapy since she was 26 years old and ovulation has occurred occasionally with improvement of the BBT pattern (Fig. 2). At the age of 27 , psychic stress developed with a marriage problem, and she fell into a state of anovulatory again (Fig. 3). In this case, beside hormon therapy, it is essential to improve the situational factor. 
The Implementation of Psychosomatic Therapy in Obstetrics and Gynecology

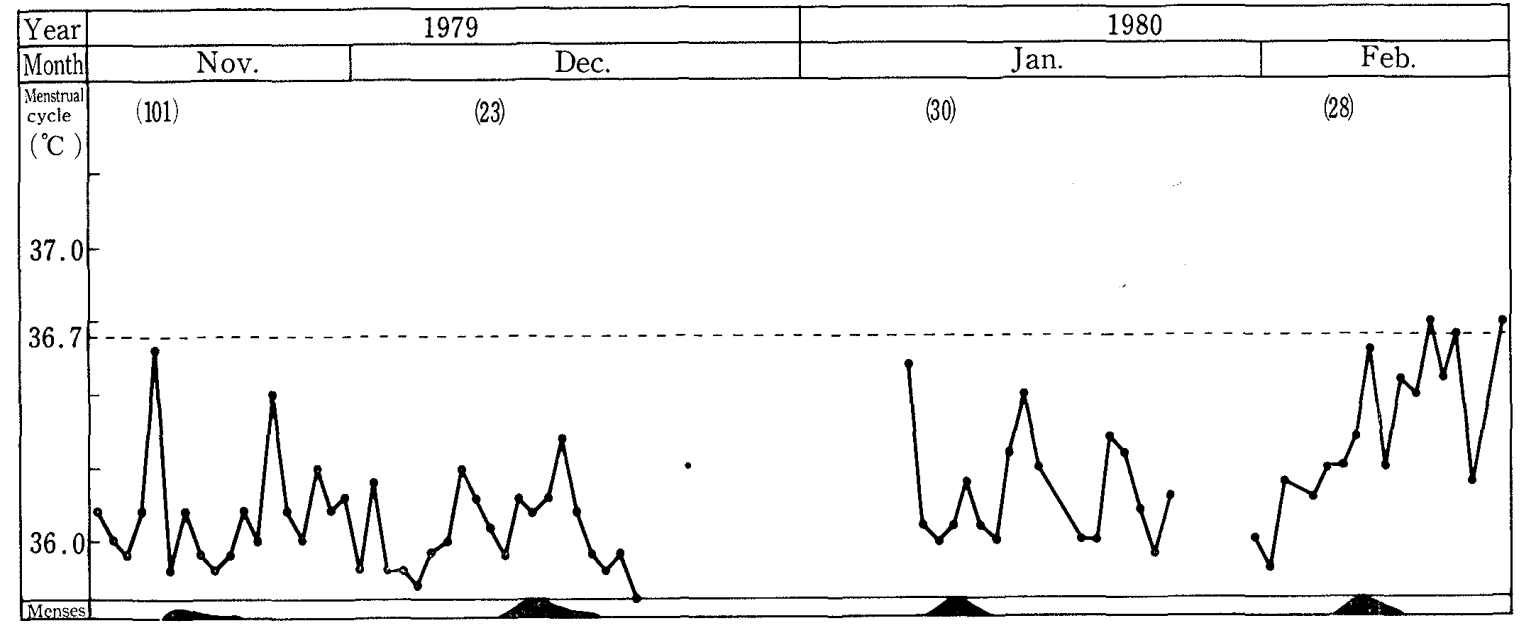

Fig. 1. M. H. 25 yrs. F. Ovarial dysfunction

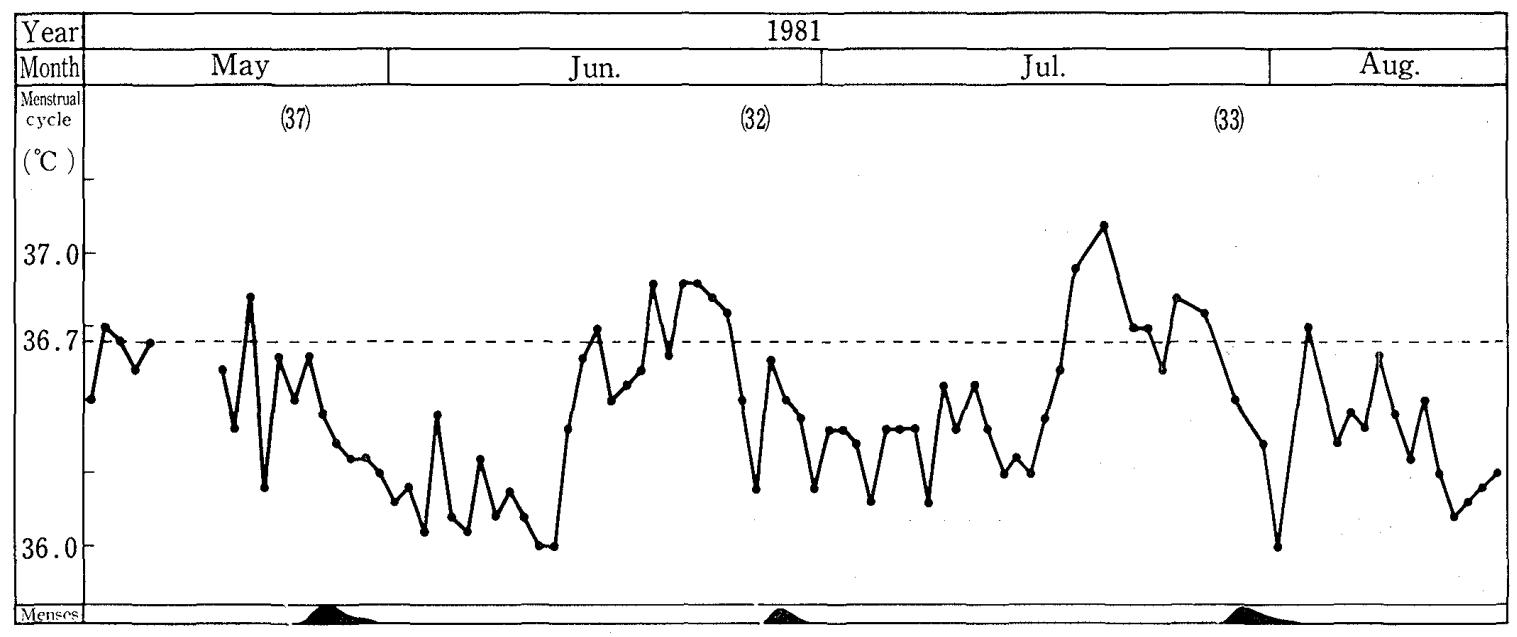

Fig. 2. M. H. 26 yrs. F. Ovarial dysfunction

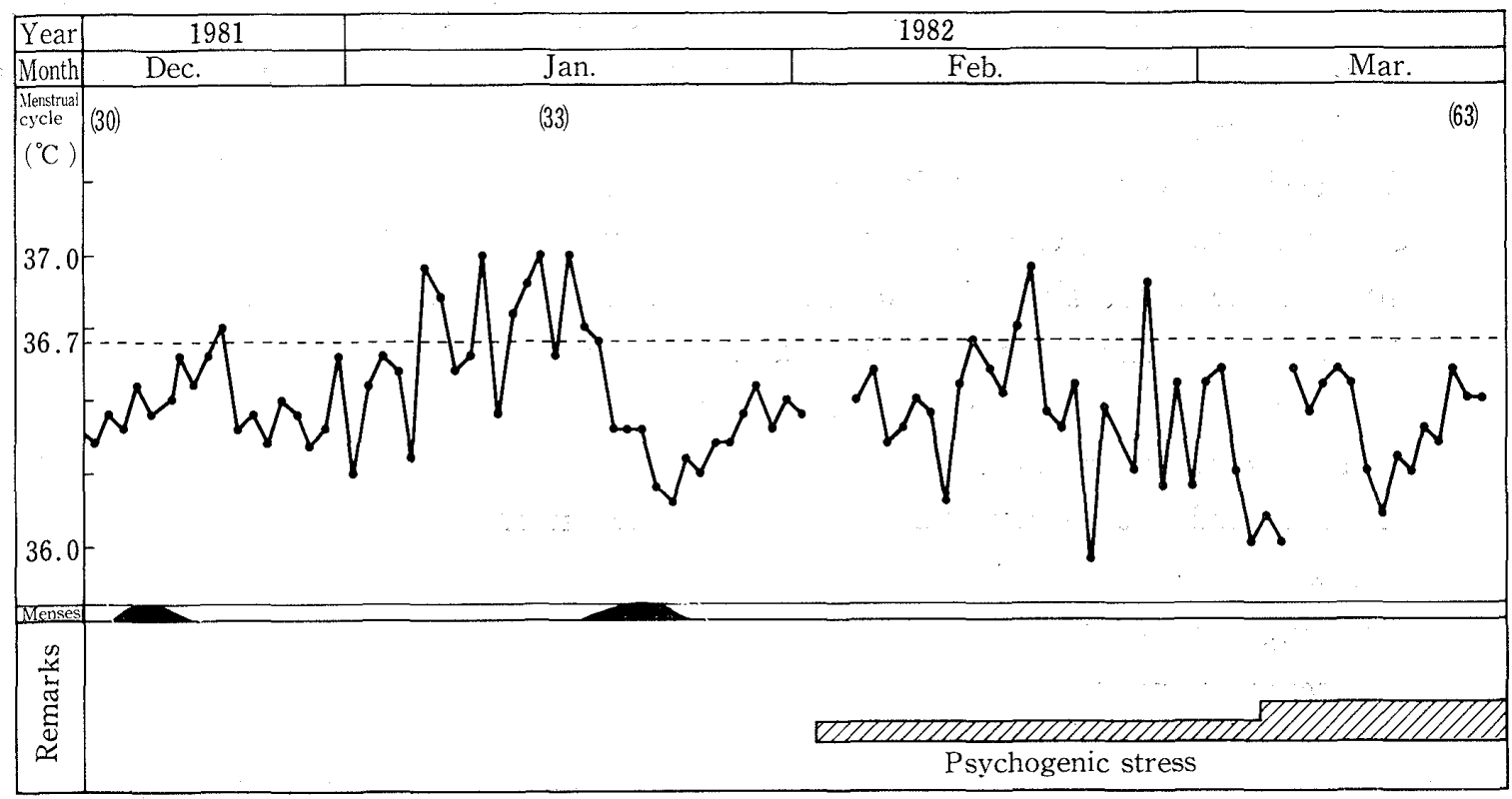

Fig. 3. M. H. 27 yrs. F. Ovarial dysfunction 
Table 2. Therapeutic guideline of disease from psychosomatic aspects

$\mathrm{f}_{1} \begin{cases}\mathrm{x}: & \text { Psychothental therapy } \\ \mathrm{y}: & \begin{array}{l}\text { Psychogenic situational } \\ \text { approach }\end{array}\end{cases}$
$\mathrm{f}_{2} \begin{cases}\mathrm{x}: & \text { Non existence } \\ \mathrm{y}: & \text { Somatic situational approach }\end{cases}$

II. The Treatment in Psychosomatic Therapy

1. Therapeutic guideline of disease viewed from psychosomatic relation

The author's therapeutic guideline is shown in Table 2. In $\mathrm{x}$ factor of psychogenic fitness $f_{1}$, psychotherapy is necessary and to $y$ factor, the adjustment of psychogenic situation is important. In $\mathrm{x}$ factor of somatic fitness $\mathrm{f}_{2}$, no radical therapeutic method exists at this time. In $\mathrm{y}$ factor, the somatic situational adjustment is important. Described above is a fundamental treatment method for each factor, and drug therapy, physical therapy and surgery may be used as supplemental therapy.

2. The treatment method on psychic factor

The fundamental treatment on $f_{1}(x)$ is psychotherapy, and for $f_{1}(y)$ is the psychogenic situation approach. Psychotherapy can be divided into insight therapy, expressive psychotherapy, supportive psychotherapy and training therapy. The characteristic features of these psychotherapies are listed as follows:

a) Insight therapy: This is a therapy aiming at the voluntary change in self consciousness of the patient's life attitude or distortion of her own character. Psychoanalytic therapy against subconcious conflict is a classical example of such therapy, and many methods of psychotherapy at the present time are concentrated on this point.

b) Expressive psychotherapy: In the patient with a strong introspective character, growing and in psychic tension, this therapy aims at releasing emotional stress through the expression of emotional experience by speech or attitude.

c) Supportive psychotherapy: This is a therapy to support the patient by encouragement or giving assurance, and also using recreation and distraction. The former is a persuation on no evidence of organic change from the results of several physical and laboratory examinations. The latter includes recreational therapy and work therapy.

d) Training therapy: The most typical training therapy is Morita therapy and autogenic training.

Secondly, the author would like to present a case of successful induction of ovulation using 
psychotherapy and the psychogenic situational approach.

Case 2. S. T. 26 years old, female, housewife.

$$
\left\{\begin{array}{l}
f_{1}(x \cdot y t) \\
f_{2}(x \cdot y t)
\end{array}\right.
$$

Chief complaint: desire for a baby

The patient had menarche at the age of 14 and has never been pregnant during the 9 years since her marriage when she was 17 years old. During the past 5 years, she has undergone care infertility workup and hormon therapy at several hospitals but could not achieve pregnancy. She was told that hysterosalpingography revealed bilateral patent fallopian tubes and a semen analysis of her husband showed no abnormality. BBT was taken occasionally and it showed a low monophasic pattern. She was quite enthusiastic to visit our clinic to receive hormon therapy, however, she failed to attain ovulation. This was followed by visits and treatments at another three hospitals but the diagnosis was always a hypoplastic uterus.

Clinical examination revealed no abnormality in the pelvis and no organic pathology in the endocrinological study. The final diagnosis by a psychological test showed apparently normal character, however, a mild hypersensitivity was recognized in situational adaptation. The following facts were disclosed during an interview. The patient was born as the eldest daughter and her husband was married into her family. Also they were living together with both her parents, grandmother and her sister. All members have been living together since her marriage during which period there was a constant quarrel between husband and his father-in-law with an accompanying act of violence. The patient has been involved in this trouble between husband and father. BBT showed low monophasic pattern.

Accordingly psychotherapy, namely psychoanalytic therapy against subconcious conflict and supportive psychotherapy against hypersensitivity of her character were carried out. The family members were called for a friendly talk and it was explained that anovulation was caused by emotional stress and that it was very important to get the cooperation of all the family members. The effort resulted in the psychotic reconciliation of the family and in adjustment of family situation. Also one cycle of puls stimulation was given (three times, every other day) and this was followed by occurrence of ovulation and pregnancy. Finally the patient gave birth to a healthy baby ten years after marriage.

In the United States, doctors in family practice, internal medicine, pediatrics and obstetrics and gynecology take charge of primary care. The problems of primary care are mainly involved with the respiratory, cutaneous, mucosheletal, psychiatric and obstetric systems. In practical medical education, only family medicine includes these systems. Accordingly the most appropriate physician to take charge of primary care is a specialist 
in family medicine. However, the specialist system in primary care is not yet established in Japan. It is important to continue further efforts in diagnosis and treatment from the bio-psycho-social aspect within related fields.

\section{References}

Okamura, Y., Kawano, K., Hamasaki, K. et al. (1982): Psychoneuroendocrine aspects in psychoand somatic environmental factors. In: Advances in Psychosomatic Obstetrics and Gynecology. Springer-Verlag, Heidelberg. p. 140.

Okamura, Y., Kitazima, M., Arakawa, K. et al. (1971): Psychosomatic aspects of gynecological endocrine diseases. Psychosomatic infertility. In: International Congress Series No. 278 (ISBN 903190177 3) Fertility and Sterility, Proceedings of the 7th World Congress. Excerpta Medica, Amsterdam. pp. 965-967.

Okamura, Y., Kitazima, M., Arakawa, K. et al. (1974): Psychoneuroendocrine aspects in gynecology and obstetrics. In: Psychoneuroendocrinology. S. Karger AG, Basel. pp. 48-55.

産婦人科に扮ける全人的医療の実践

岡 村 靖

産業医科大学産婦人科学教室

要 旨：疾患の発症機序について，心理学，内分泌学および自律神経学の 3 方面から，系統的な考

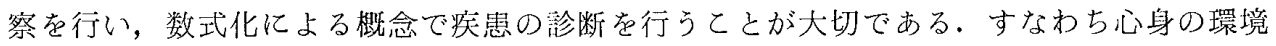
因子についても息断上留意するてとが大切である。てのような讋断を行うためには臨床心 理士やケースワーカーとのチーム医療を組むととである．筆者はこの見地から䠛床例につ いて解析する．米国ではプライマリ・ケアを担当するものとして，家庭医学，内科，小児 科ならび崖㖊人科が考光られており，プライマリ・ケアの専門医制度も育っている。し かし，日本ではプライマリ・ケア專閒医の制度が未だ設置されていないので，関連各科で， bio-psycho-social な面からの診断治療に努力するととが大切である.

J. UOEH（産業医大芯），4(4)：543-548（1982） 